(c) 2020, The Authors. Published by FASS Inc. and Elsevier Inc. on behalf of the American Dairy Science Association ${ }^{\circledR}$. This is an open access article under the CC BY-NC-ND license (http://creativecommons.org/licenses/by-nc-nd/4.0/).

\title{
Changes to steps, lying, and eating behavior during lactation in Jersey and Holstein cows and the relationship to feed intake, yield, and weight
}

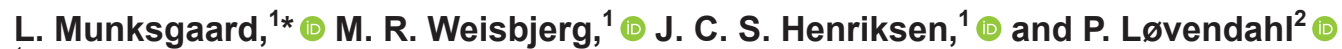 \\ ${ }^{1}$ Department of Animal Science, Aarhus University, Blichers Allé 20, 8830 Tjele, Denmark \\ ${ }^{2}$ Department of Molecular Biology and Genetics, Aarhus University, Blichers Allé 20, 8830 Tjele, Denmark
}

\begin{abstract}
Devices that record behavior automatically have made it possible to accurately measure the lying and eating behavior of large numbers of dairy cows. During lactation, weight, feed intake, and production of cows change; however, longitudinal studies of how the behavior of dairy cows is correlated with production traits during lactation are limited. This study describes changes in duration of lying and eating behavior throughout lactation and how these variables are related to changes in milk yield, live weight, and feed intake in lactating primi- and multiparous Holstein and Jersey cows. Data were from 255 cow lactations (43 primiand 80 multiparous Jersey cows, and 56 primi- and 76 multiparous Holstein cows) from 5 to $200 \mathrm{~d}$ in milk. Leg-mounted tags were used to record lying time and steps; ad libitum feed intake (of a partial mixed ration) variables were recorded from feed bins on weight cells; and milk yield and live weight were recorded during automatic milking, all on a daily basis. The lactation trajectory was split into 4 segments. Data were analyzed using mixed effects linear models. Holstein cows spent more time lying and eating than Jersey cows, whereas Jersey cows had a greater number of steps (25-37\%). First-lactation cows spent less time eating and had more steps than older cows. Average daily lying time was approximately $1 \mathrm{~h}$ longer during February than the shortest lying time, which was observed in August. Both Holstein and Jersey multiparous cows had longer lying times than cows in first parity after parturition; however, the lying time of multiparous cows decreased, whereas that of primiparous cows increased in the beginning of lactation. Later in lactation, older cows tended to increase duration of lying more than younger cows did. The daily change in behavior (lying, eating, and steps) and milk yield, live weight, and dry matter intake, characterized as slopes in the lactation period
\end{abstract}

Received September 9, 2019.

Accepted January 18, 2020.

*Corresponding author: lene.munksgaard@anis.au.dk for each cow, were not strongly correlated. However, we found a moderate correlation between changes in milk yield and dry matter intake, and between changes in eating time and rate of eating. An increase in eating rate in multiparous Holstein cows was correlated with increasing lying time. In conclusion, the use of automated behavior recording enabled thorough investigations of relationships between a range of behavior traits and frequently recorded production traits, and revealed that patterns of change during lactation are strongly affected by breed and parity.

Key words: behavior, parity, breed, days in milk

\section{INTRODUCTION}

Over the last decade, the introduction of devices that automatically record behavior has led to a large increase in the number of studies describing the lying and eating behavior of dairy cows in relation to housing and management (e.g., EFSA, 2009), feeding (e.g., Henriksen et al., 2019), and health (e.g., Thorup et al., 2015). Behavior-recording technologies have also become available for commercial use over the last few years, which will lead to new opportunities for precision livestock farming (Caja et al., 2016).

Previous studies suggest that stage of lactation has a large effect on daily lying time, with lying time increasing by around $2 \mathrm{~h}$ over the lactation period (Bewley et al., 2010; Vasseur et al., 2012; Løvendahl and Munksgaard, 2016; Solano et al., 2016; Westin et al., 2016). These results were based on cross-sectional studies that only recorded the behavior of each cow over a few days during different stages of lactation and, in some cases, using only a few stages of lactation. However, a recent longitudinal study showed that lying time decreases during the first month of lactation, after which it increases and then reaches a plateau in the last part of lactation (Maselyne et al., 2017). There is also some evidence, albeit limited, that eating behavior changes during lactation. Huzzey et al. (2006) observed an increase in eating time during the first week of lactation, and eating time seems to increase to a plateau, which 
might be related to peak yield (DeVries et al., 2003; Norring et al., 2014). Parity also influences lying and eating behavior (Sepúlveda-Varas et al., 2014; Westin et al., 2016; Stone et al., 2017), but not in all studies (Chaplin and Munksgaard, 2001; Brzozowska et al., 2014). Cows of different breeds, such as Holstein and Jersey, also exhibit different lying and eating behaviors (Campler et al., 2018; Henriksen et al., 2019). Thus, we could expect that eating and lying behavior, and perhaps activity, change during lactation, but information is scarce on how such changes are affected by breed and parity.

Both milk yield and feed intake increase during the first weeks of lactation, and then typically decrease slowly until the end of lactation (Bossen and Weisbjerg, 2009; Li et al., 2018). In contrast, the live weight of dairy cows typically decreases in the beginning of lactation, after which it increases to a plateau late in lactation, depending on the feeding strategy and level of milk yield (Bossen et al., 2009; Li et al., 2018). However, despite these rather large changes in weight, feed intake, and production during lactation, there are very few longitudinal studies on the behavior of dairy cows, particularly when considering changes in the time budget and the production-related variables depending on stage of lactation. We expected duration of eating as well as duration of lying to increase during lactation and the number of steps to decrease. Furthermore, we expected that individual cow changes in yield and feed intake, affecting the weight of the cows, may also lead to increased motivation to eat and thus less time spent lying. Thus, we predict that a change in duration of lying may follow a weight change in individual cows. However, there is only limited knowledge about the relationship between changes in behavior and changes in production variables. Therefore, in this paper, we describe changes in duration of lying and eating per day as well as the number of steps during lactation and how these changes are related to each other and to changes in milk yield, weight, and feed intake in lactating primi- and multiparous Holstein and Jersey cows. Furthermore, because production variables can be affected by season, we also investigated the effect of season.

\section{MATERIALS AND METHODS}

Data were collected at the Danish Cattle Research Facilities at Aarhus University (Tjele, Denmark) from February 2015 to February 2017. Data are from 2 experiments studying strategies for feeding concentrate in the milking robot. In both experiments, a control treatment was compared with experimental treatments with different types of adjustments in concentrate allowance in the robot (Henriksen, 2019). Treatment was included in the statistical analysis of the current study to adjust for variation due to treatment; however, a description of the exact treatments and effects of the treatments is provided by Henriksen (2019). Hence, for the current study, the cows were studied as a single cohort allocated to various treatments. This study reports the effect of breed, parity, and stage of lactation and the relationship between these variables throughout lactation, focusing on daily changes in the variables.

\section{Animals and First Data Filtering}

In total, data from 255 lactations (219 cows) were included in the analysis [Jersey: 43 primi- and 80 multiparous (parity $=3.19 \pm 1.21$ ); Holstein: 56 primi- and 76 multiparous (parity $=2.78 \pm 0.96$ )]. The average milk fat and protein levels were 5.99 and $4.27 \%$ in Jersey and 3.89 and $3.42 \%$ in Holstein, respectively. Cows calved year round ( 8 to 14 calvings/mo). Cows were included in experiment 1 until d 240 of lactation, and in experiment 2 until the experiment ended on January 31, 2017. Because of culling and the specific end date, the number of cows included in the analysis decreased steadily with DIM. Furthermore, because of technical problems, some data were missing and, occasionally, cows were moved to a smaller, separated area for a shorter period for treatment or insemination. Therefore, data were filtered as explained here to ensure the quality and quantity of the data from each cow for analysis. Visual inspection of data suggested that cows that were culled before the end of 240 DIM or before the end of experiment 2 may have had abnormal responses, probably due to disease in the last weeks before culling; therefore, the last $3 \mathrm{wk}$ of observations were excluded for these cows. Occasionally, some cows were kept in a separate area. Therefore, data from days when cows ate from feeders positioned in another section of the barn were excluded. If data were missing for more than 7 consecutive days, data from the remaining period of lactation for that specific cow were excluded. Due to technical problems, data from $7 \mathrm{~d}$ in the fall of 2016 from all cows were missing. However, data were still included afterward. Data from the AfiTagII tags (lying time and steps; Afimilk, Afikim, Israel) that were above or below the 99th and 1st percentiles were considered extreme and were removed.

To assess changes over lactation and to analyze relationships between variables, the lactation was divided into 4 periods based on visual inspection of graphs on the duration of lying time and eating time of partial mixed ration (PMR), with the last period ending at 200 d. In summary, data were included only from d 5 of lactation until d 200. The number of cows from each 
Table 1. Number of cows in each breed, parity, and stage of lactation ${ }^{1}$

\begin{tabular}{lcclcc}
\hline & \multicolumn{2}{c}{ Holstein } & & \multicolumn{2}{c}{ Jersey } \\
\cline { 2 - 3 } \cline { 5 - 6 } DIM & Parity 1 & Parity $>1$ & & Parity 1 & Parity $>1$ \\
\hline $5-35$ & $52(50)$ & $65(63)$ & & $31(30)$ & $71(71)$ \\
$36-75$ & $52(51)$ & $65(65)$ & & $40(39)$ & $78(78)$ \\
$76-120$ & $43(43)$ & $57(57)$ & & $36(35)$ & $65(65)$ \\
$121-200$ & $33(32)$ & $53(53)$ & & $29(28)$ & $58(58)$ \\
\hline
\end{tabular}

${ }^{1}$ Numbers in parentheses are cows with data during the specific period used for the analysis.

breed, parity, and stage of lactation is shown in Table 1.

\section{Housing and Feeding}

Cows were kept in a loose-housing system in 2 groups, with one breed per group. The groups each had free access to one milking robot (VMS, DeLaval International AB, Tumba, Sweden) and with at least one cubicle $(1.80 \mathrm{~m} \times 1.20 \mathrm{~m}$ and $1.55 \mathrm{~m} \times 1.10 \mathrm{~m}$, length to brisket board, for Holstein and Jersey, respectively) per cow bedded with geotextile mattresses (Cowtex, Tromborg, Denmark) topped with a thin layer of a mix of cut wheat straw and sawdust. The alleys had slatted floors in the alleys, and the slatted floor was covered with rubber in front of the robot. The cows were fed concentrate in the robot according to 2 strategies: either at a flat rate (control) or using an individual strategy. The concentrate allowance was $3 \mathrm{~kg} / \mathrm{d}$ for the control treatment after the first $2 \mathrm{wk}$. For cows assigned to the individual concentrate strategy, concentrate allowance varied between 2 and $10 \mathrm{~kg} / \mathrm{d}$. The cows were offered pelleted concentrate in the robot. All cows had ad libitum access to a PMR (concentrate:forage ratio, 35:65), including (\% of DM) corn silage (38.4), grass-clover silage (26.3), rapeseed cake (12.1), NaOHtreated wheat (9.8), artificially dried sugar beet pulp (7.9), soybean meal (3.5), and mineral-vitamins (2.0) in individual computer-operated feeding bins (RIC system, Insentec B.V., Marknesse, the Netherlands). Fresh feed was delivered 4 times a day. Twenty-seven feed bins were available in the Holstein section (range 1.8 to 2.3 cows/bin) and 25 in the Jersey section (range 1.9 to 2.6 cows/bin).

\section{Data Recording}

Behavior and Feed Intake. An activity pedometer (AfiTagII, AfiMilk, Afikim, Israel) was attached to one hind leg of each cow to record the daily lying time and number of steps. Daily lying time was calculated as described in Henriksen and Munksgaard (2019). Eating time, feeder visits, and feed intake $(\mathrm{kg})$ were calculated based on data from the RIC system, including the time and duration of each visit. Data were cleaned using the method described by Bossen et al. (2009).

Visits to the Robot. Complete milkings, incomplete milkings, and rejected milking attempts were recorded by the automatic milking system. The settings for the robot are described in Henriksen et al. (2019).

\section{Milk Yield and Content}

Milk yield $(\mathrm{kg})$ was recorded in the robot at every milking, and daily yield $(\mathrm{kg})$ was calculated by summing the yields of the present day and interpolation over yields recorded on the last milking of the preceding day and on the first milking of the following day.

\section{Daily Live Weight}

Each robot had a weighing platform that recorded the live weight of the cow at each milking (Danvaegt, Hinnerup, Denmark). Daily live weights were calculated according to the method described in Bossen et al. (2009).

\section{Statistical Analysis}

The following variables were used in the models described below: lying time $(\mathrm{min} / \mathrm{d})$, eating time $(\mathrm{min} / \mathrm{d})$, live weight $(\mathrm{kg})$, feed intake $(\mathrm{kg}$ of $\mathrm{DM} / \mathrm{d})$, eating rate $(\mathrm{g} / \mathrm{min})$, and milk yield $(\mathrm{kg} / \mathrm{d})$.

The longitudinal data were obtained over 2 calendar years; thus, seasonal effects were expected and assigned to calendar months within each year. Parity groups were defined as primiparous and multiparous.

The effects of month and year, as well as the overall effects of breed and parity group, plus treatment and their interactions were initially analyzed with a linear mixed model [1], using the MIXED procedure in SAS (version 9.3, SAS Institute Inc., Cary, NC); DIM was included as a covariate. Cows within breed and parity were included as random effects to account for covariance among repeated records within lactation on the same cow:

$$
\begin{aligned}
y_{i j k l m n p}=\mu+B_{i} & +P_{j}+B P_{i j}+T_{k}+T B_{i k}+T P_{j k} \\
+R Y_{l}+ & M_{m}+R Y M_{l m}+\beta \times D I M \\
& +C_{i j k l m}+\varepsilon_{i j k l m n p}
\end{aligned}
$$

where $y_{i j k l m n}$ is the observed value of trait $y ; \mu$ is the intercept; $B$ is the effect of breed $i$ (Jersey or Holstein), $P$ is the effect of parity group $j(1$ vs. $>1)$, and $B P$ 
is the interaction between $B$ and $P ; T$ is the effect of treatment $k$ and $T B$ and $T P$ are interactions between treatment and breed and parity; $R Y$ is effect of recording year $l, M$ is effect of recording month $m$, and $R Y M$ is their interaction; $\boldsymbol{\beta} \times D I M$ is the linear regression of trait $y$ on DIM; $C$ is the random effect of cow within parity, breed, and treatment; $n$ is the period; $p$ is the observation within period $n$; and $\varepsilon$ is the residual. The covariance structure was compound symmetry because this variance structure gave the lowest Akaike information criterion value; we used the containment method for degrees of freedom.

To assess the changes in variables during lactation, changes were estimated over shorter time intervals by linear regression. The lactation trajectory was divided into 4 periods: 1: DIM 5-35, 2: DIM 36-75, 3: DIM 76-120, and 4: DIM 121-200. An additional filter was applied to qualify data for this analysis, so that, for each period, at least 15 observations were required for each cow, with least 3 observations during the first $5 \mathrm{~d}$ of a given period and at least 3 observations in the final $5 \mathrm{~d}$ of the same period. A total of 818 cow-breed-parity periods qualified for this analysis. Within each period, the rate of daily change in each variable was estimated as the slope $\boldsymbol{\beta}$ on DIM for each cow within each parity using model [2]:

$$
y_{n p}=\mu_{n}+\boldsymbol{\beta}_{n} D I M+\varepsilon_{n p} .
$$

The obtained slopes were then analyzed for the effects of breed and parity using the MIXED procedure in SAS with the fixed part of model [1]. Calving year and calving month were included instead of recording year and month. Correlations between slopes of variables within each period of lactation were estimated as Pearson correlations within breed-parity groups for each period (CORR procedure, SAS Institute Inc.). The significance of correlations between each set of slopes was Bonferroni-adjusted.

\section{RESULTS}

\section{Main Effects of Breed and Parity Across Lactation on Behavior, Feed Intake, Live Weight, and Yield}

Behavior and production variables recorded during the lactation period were affected by the systematic factors included in model [1], as shown in Table 2. Holstein cows spent more time lying and eating PMR than Jersey cows, whereas Jersey cows had a greater number of steps (25 to $37 \%$ more steps; Table 2). First-lactation cows spent less time eating and took more steps than older cows; however, the duration of lying did not differ significantly between first-lactation and older cows of the same breed. Feed intake, live weight, and yield followed the well-established pattern, with higher intake, weight, and yield in Holstein, and higher intake, weight, and yield of cows in later parities than in first parity (Table 2).

\section{Effect of Season and Year}

Month of the year $(P<0.0001)$ but not the year itself $(P=0.53)$ had a significant effect on lying time. However, the pattern differed between years (interactions between month and year, $P<0.0001$; Figure 1). The duration of lying varied by more than $1 \mathrm{~h} / \mathrm{d}$ across seasons. Lying time was longer during winter than during summer (with the shortest time being recorded in August; Figure 1). Both the duration of eating per day and activity were influenced by month of the year. This pattern differed between the 2 years (interaction between month and year, $P<0.0001)$. However, variation within year in the number of steps and eating duration was less pronounced than the variation in lying time.

\section{Changes in Behavior During Lactation with Respect to Breed and Parity}

Visual inspection of changes during lactation (Figure 2 ) showed that both the duration of lying and eating, as well as activity (steps per day), changed throughout lactation. These changes differed with respect to breed and parity. Older Holstein and Jersey cows had a longer lying time compared with cows in first parity at the start of lactation. However, the lying time of older cows declined noticeably over the first 6 wk of lactation. In contrast, the lying time of cows in first parity increased from the second week of lactation. First-lactation Jersey cows reached the same lying duration as older cows at an earlier stage of lactation compared with Holstein primiparous cows. The duration of eating PMR followed the same pattern during lactation; however, the levels differed between breed and parity. Primiparous Jersey cows reached the same level as multiparous Jersey cows earlier in lactation than primiparous Holstein cows. Jersey cows took more steps than Holstein cows, and in both breeds the number of steps was higher in primiparous cows than in multiparous cows during the first 2 to 3 mo of lactation. Changes to behavior, feed intake, weight, and yield during lactation were quantified as the slopes of each variable within each period of lactation (Table 3 and Table 4). The slopes for the duration of lying were not affected by breed in any part of lactation. However, the lying time of cows in first lactation increased during the first part of lactation, whereas lying time decreased in older cows. Later in lactation, older cows tended to increase duration of 
lying more than younger cows. Furthermore, the slope of change in lying time did not differ between parities during the other periods of lactation. Breed and parity did not affect the changes in number of steps, except for older cows that reduced the number of steps per day more than cows in first parity. The time spent eating for Holstein cows than for Jersey cows. Breed did not affect changes to eating time in any other part of lactation. From 36 to 75 DIM, the time spent eating PMR increased at a slower rate in multiparous cows than in first-lactation cows. In the final lactation included in this analysis, the time spent eating PMR decreased more rapidly in multiparous cows than in primiparous cows.

\section{Relationships Between Changes Within Period in Behavior, Feed Intake, Yield, and Weight}

The daily change in both the behavior and production variables characterized as slopes within each lactation period for each cow was generally only weakly correlated. This was observed for correlations between the
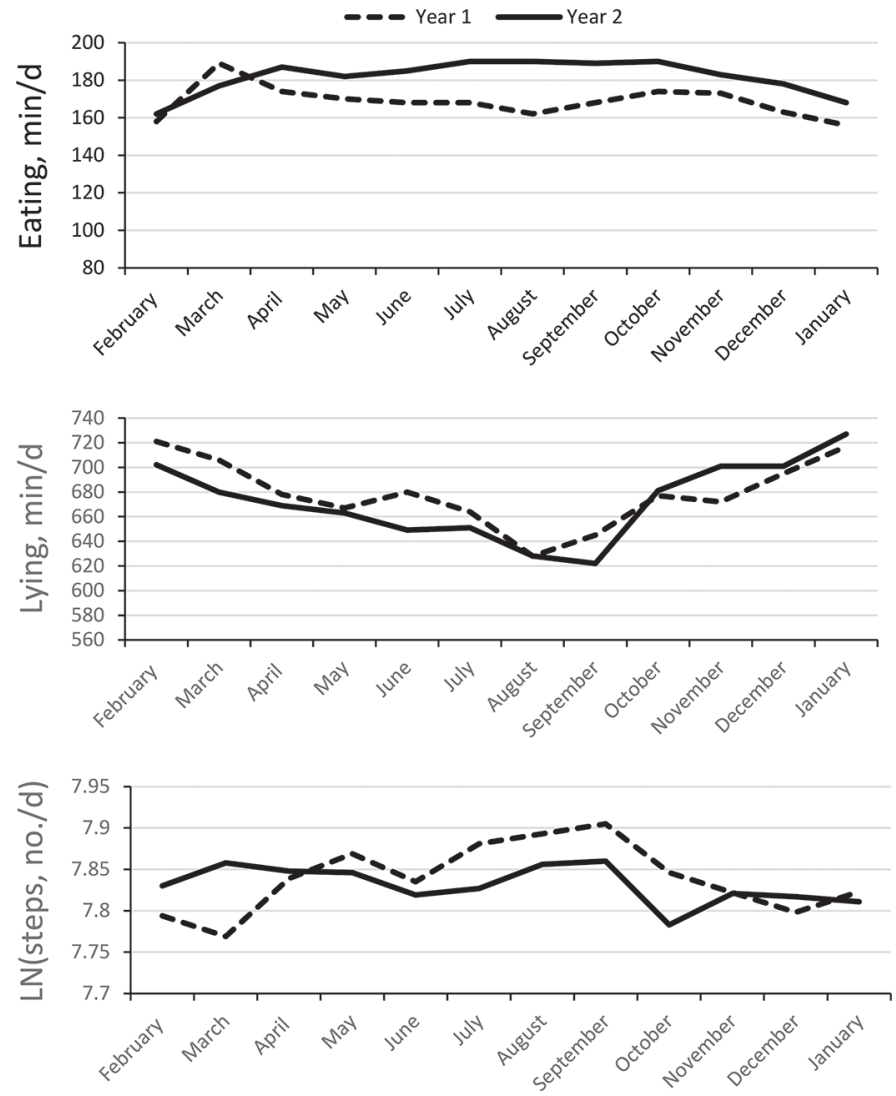

Figure 1. Changes in eating, lying, and number of steps during month of year (data collection started February 1). PMR increased faster in the first month of lactation

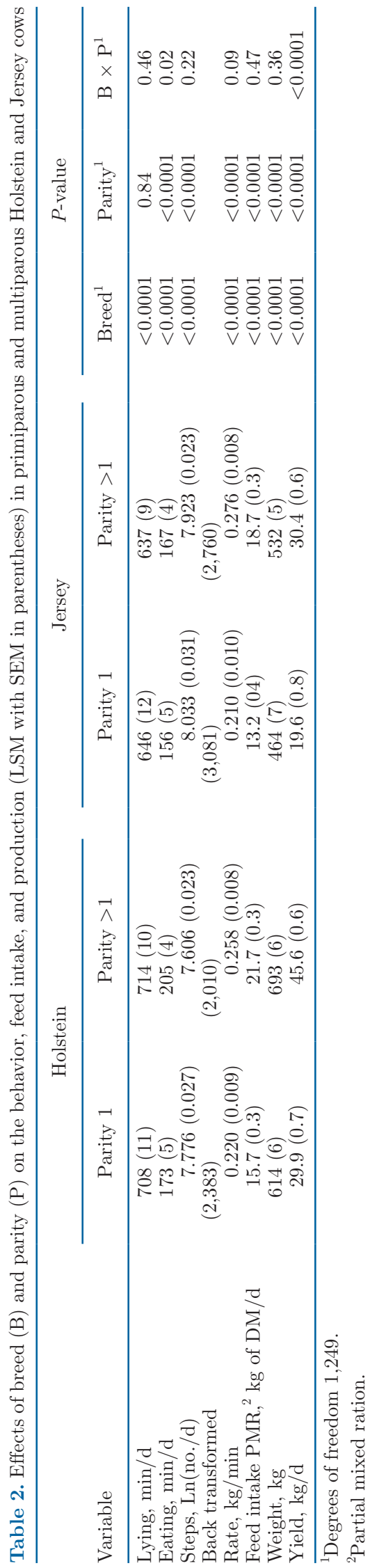

Journal of Dairy Science Vol. 103 No. 5, 2020 

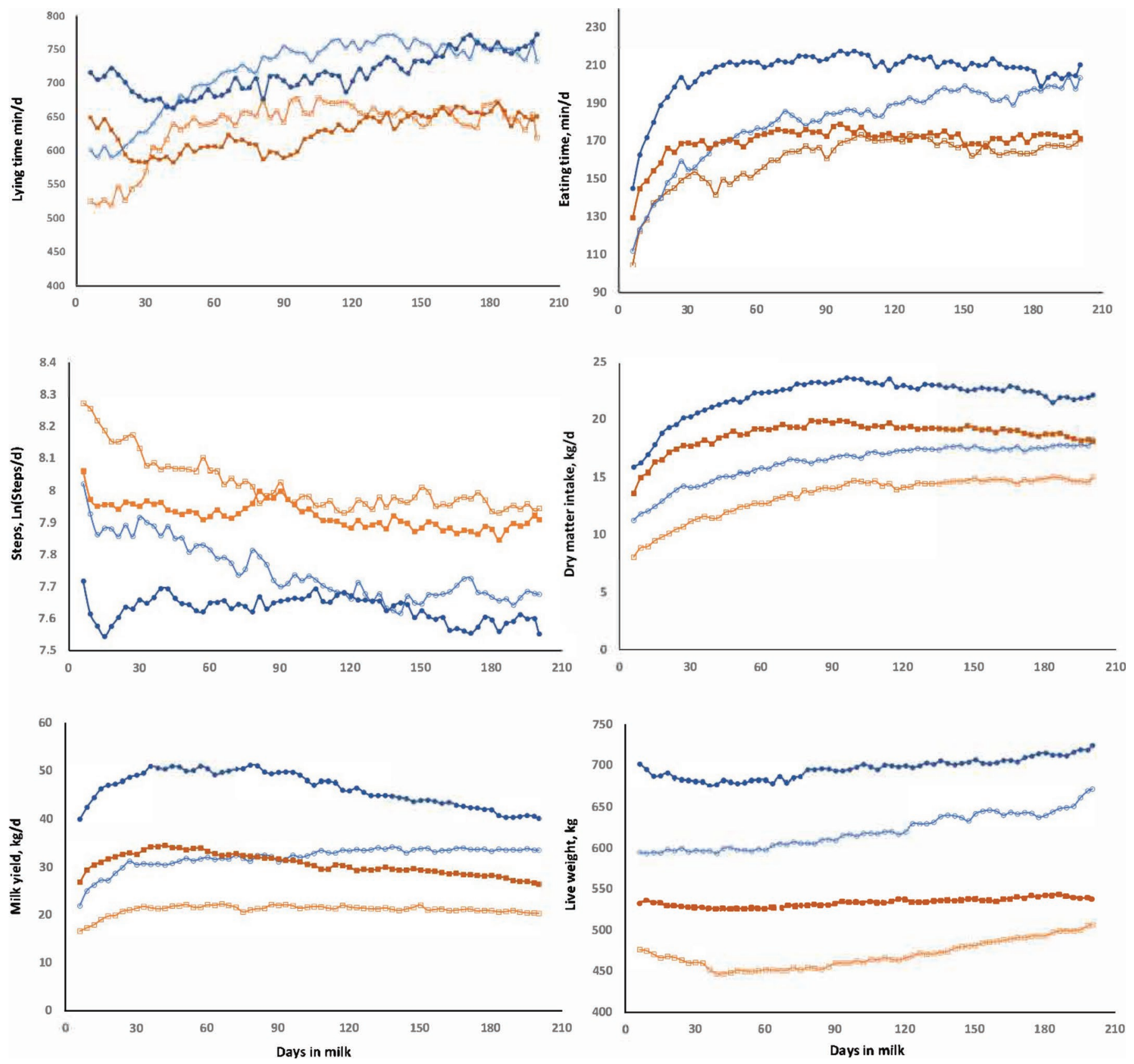

Figure 2. Behavior, DMI, milk yield, and live weight during lactation in primiparous Jersey, multiparous Jersey, primiparous Holstein, and multiparous Holstein cows. $\square$, orange $=$ Jersey parity $1 ; \mathbf{\square}$, orange $=$ Jersey parity $>1 ; \bigcirc$, blue $=$ Holstein parity $1 ; \bullet$, blue $=$ Holstein parity $>1$.

slopes of lying time and eating time, with an average of $\mathrm{r}=-0.11$ (range $\mathrm{r}=-0.56$ to 0.20 ); however, for lying time and steps, the correlations were on average moderate and negative, $\mathrm{r}=-0.47$ (range $\mathrm{r}=-0.80$ to 0.20 ). Slopes for eating time and PMR DMI were weakly to moderately correlated (mean $\mathrm{r}=0.29$, range $\mathrm{r}=-0.13$ to 0.72 ), and more in Holstein than in Jersey cows ( $\mathrm{r}$ $=0.42$ vs. 0.15 ). For slopes of eating time and yield, a similar but weaker set of correlations was found (mean $r=0.18$, range $r=-0.33$ to 0.62 ), with somewhat weaker correlations for Jersey cows compared with Holstein cows (mean $r=0.07$ vs. 0.30 ). The change in live weight was only weakly correlated with change in yield and change in DMI (mean $\mathrm{r}=0.19$ and 0.20 ; ranges $\mathrm{r}=$ -0.29 to 0.76 and -0.15 to 0.80 , respectively). Finally, a moderate correlation was found between changes in milk yield and DMI (mean $\mathrm{r}=0.38$, range $\mathrm{r}=-0.12$ to 0.75$)$. However, the correlation between the slope 
Munksgaard et al.: LYING AND EATING BEHAVIOR IN JERSEY AND HOLSTEIN

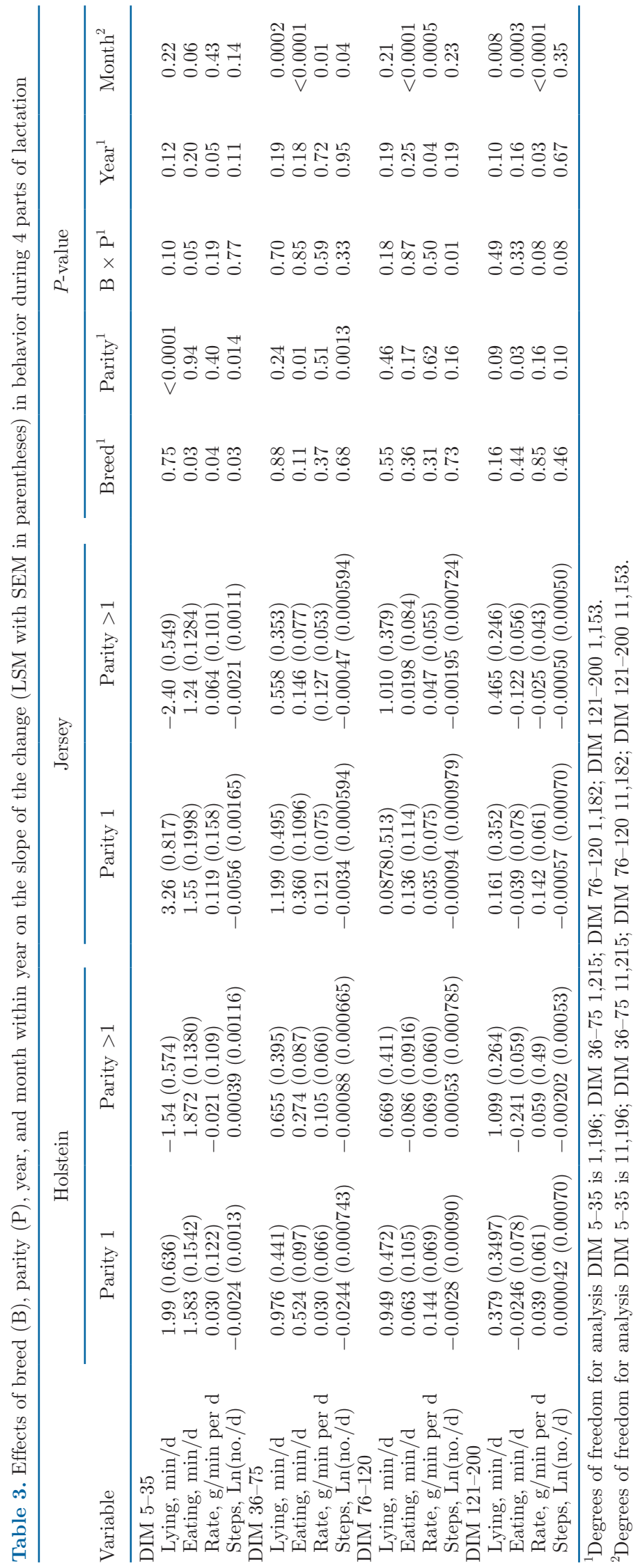


Munksgaard et al.: LYING AND EATING BEHAVIOR IN JERSEY AND HOLSTEIN

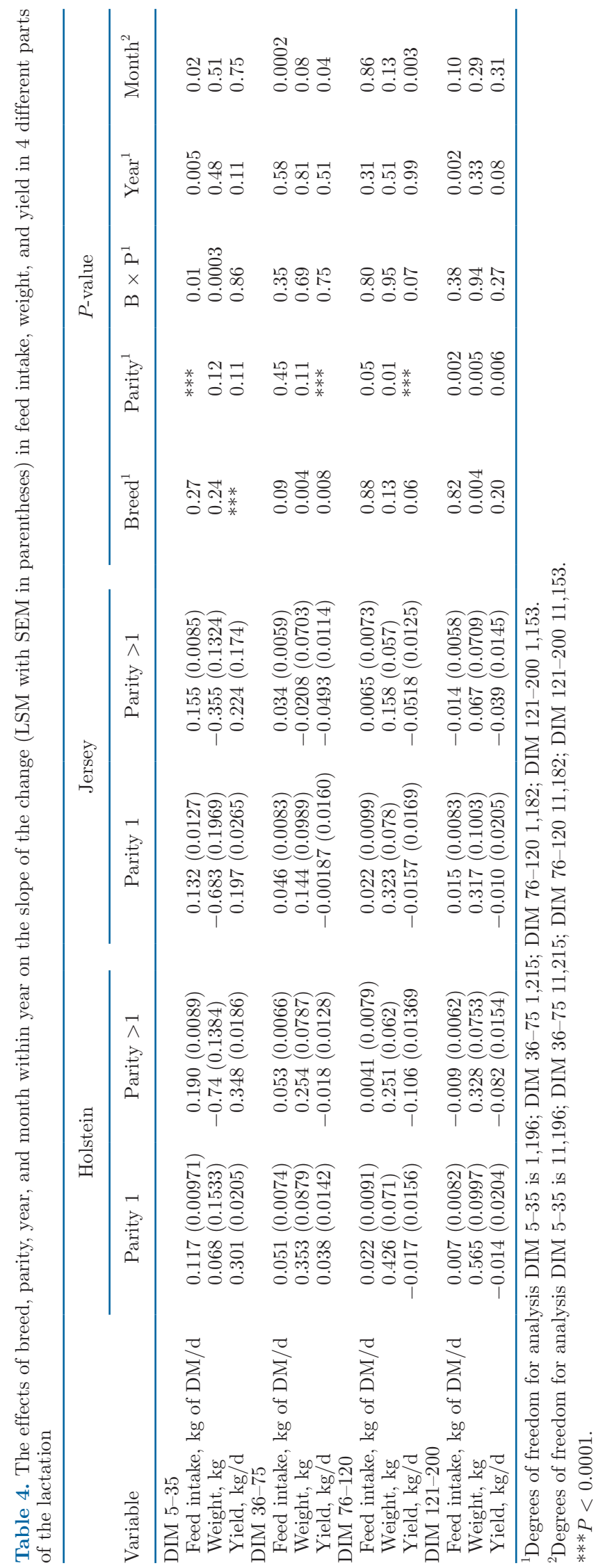

of the rate ( $\mathrm{g}$ of $\mathrm{DM} / \mathrm{min}$ ) and eating time was always negative and high (mean $\mathrm{r}=-0.67$; range, $\mathrm{r}=-0.43$ to -0.87 ), whereas the correlation between the slope of the rate and lying time was very low in Jersey cows (range -0.12 to 0.27 ). We detected a consistent, moderate correlation in multiparous Holstein cows (mean $\mathrm{r}=0.32$, range $\mathrm{r}=0.25$ to 0.40 ) throughout lactation and in primiparous cows when DIM exceeded $75(\mathrm{r}=$ 0.52 for DIM $76-120$ and $\mathrm{r}=0.47$ for DIM 121-200).

\section{DISCUSSION}

The results showed distinct trajectories of changes in the level of steps and the duration of lying and eating per day during lactation. The trajectories of the behavior differed considerably between primiparous and multiparous cows, with breed also influencing the rate of eating. Season also influenced the behavior of the cows. There were few and weak correlations between the daily slope of behavior and yield, feed intake, and weight changes during the 4 periods of lactation.

Data were collected in a herd with a relatively high yield compared with the milk production level in Denmark and North America (Kristensen et al., 2015; USDA, 2019). The duration of lying time was in the upper end of the interval seen in many other herds (Ito et al., 2009; Thomsen et al., 2012), and at a level that suggests most cows can properly fulfill their need for lying. In contrast, the duration of eating was relatively short compared with that reported in similar studies (Beauchemin, 2018), which may be due to the stocking density at the feeders or the special design of the feeders used for research purposes.

\section{Changes to Behavior During Lactation}

Lying time decreased for older Jersey and Holstein cows during the first $6 \mathrm{wk}$ of lactation, in agreement with Maselyne et al. (2017) and Arazi et al. (2010). However, this study was the first to demonstrate that primiparous cows have different trajectories from multiparous cows, starting with a shorter lying time in the beginning of lactation but with no decrease in lying time during the first weeks of lactation. Primiparous cows might be more affected by being introduced to the lactating group after parturition, potentially resulting in a shorter lying time initially. Sepúlveda-Varas et al. (2014) also found that primiparous cows spent less time lying than multiparous cows during the first weeks of lactation. Compared with older cows, primiparous cows had a lower production level and spent less time eating during the first months of lactation. The amount of time spent eating might have affected both their motivation to lie down and the time available 
for lying down, possibly explaining the increase rather than decrease in the duration of lying. Furthermore, because primiparous cows are still growing, they might prioritize lying more than older cows (Hänninen et al., 2003). Alternatively, multiparous cows might be more influenced by a greater amount of milk in the udder at the beginning of lactation. There is some evidence that discomfort due to large amounts of milk in the udder reduces lying time (Österman and Redbo, 2001; Norring et al., 2012), although not necessarily during dry-off (Zobel et al., 2015). Finally, cows spent more time on social contact and visited other animals more often in early lactation than later in lactation (Munksgaard et al., 2005). Thus, further research is required to understand the mechanism driving changes in lying time during the first months of lactation among cows of different parities.

The duration of eating increased in Jersey and Holstein cows of both parity groups during the first period of lactation, supporting previous studies (DeVries et al., 2003; Dohme-Meier et al., 2014). In addition, during early lactation, changes to eating time were faster (shown as a steeper slopes of increase) in Holstein cows than in Jersey cows. The duration of eating reached a plateau in multiparous cows approximately 1 mo into lactation, whereas their DMI first peaked at 3 to 4 mo into lactation. This observation supports a greater increase in the rate of feeding in multiparous cows than in primiparous cows. The eating time of primiparous Holstein cows continued to increase until later in lactation; however, primiparous Jersey cows reached the same eating time as multiparous Jersey cows before primiparous Holstein cows. Norring et al. (2014) also recorded shorter eating times in primiparous cows than in multiparous cows, with eating time increasing with increasing DIM. In contrast to our study, eating rate decreased with increasing DIM in the study by Norring et al. (2014). However, competition for access to feed bins might limit eating time (e.g., Huzzey et al., 2006) and increase eating rate (e.g., Olofsson, 1999). In our study, the stocking density of the feed bins was rather high. This may have increased the eating rate, particularly in the older cows with high production who needed a high-energy intake; multiparous cows might also be under some time constraint to obtain both enough eating and lying time at peak production.

For both primi- and multiparous cows, the number of steps decreased during the first 2 wk of lactation. Primiparous cows took more steps than multiparous cows. Later on, the number of steps declined, with primiparous and multiparous cows reaching the same level from around 3 mo into lactation. Thereafter, both primiparous and multiparous cows showed a slight decrease in activity toward DIM 200. Brzozowska et al. (2014) found similar trends in steps per day with increasing DIM; however, the authors did not distinguish between parities. In contrast to Løvendahl and Chagunda (2006) and Reader et al. (2011), we found a reduction in activity during the first part of lactation. However, in our study, a leg-based device was used to record activity, whereas neck-based devices were used to record activity in the other studies. The changes in yield, weight, and DMI showed typical lactation curves (Henriksen et al., 2019) and will not be discussed further here.

\section{Seasonal Effects}

The lying behavior of cows in our study changed by as much as $1 \mathrm{~h} / \mathrm{d}$ from summer to winter months. Similar results were reported for studies conducted in Poland and Israel (Brzozowska et al., 2014; Arazi et al., 2010; Steensels et al., 2012). These results might be due to heat stress, as previous studies found that cows lie down less during heat stress (e.g., Galán et al., 2018). However, in our study, the change in lying time occurred gradually over several months, during which temperature and humidity changes (average temperature per month, range from 1.9 to $17.1^{\circ} \mathrm{C}$, and average humidity 76.8 to $88.8 \%$; https://www.dmi.dk/ vejrarkiv/) were minor and within the range that cows can adjust to relatively easily (Buffington et al., 1981; EFSA, 2009). Thus, factors other than temperature, such as light intensity, might influence the duration of lying per day. In contrast, Shan et al. (2019) recorded shorter lying times in winter than in summer, but Shan et al. (2019) suggest that this difference was due to the high water content of the fermented cow manure used as bedding, which might lead to discomfort during winter. Thus, climate factors that might have indirect effects on lying behavior could contribute.

\section{Relationship Between Changes in Behavior and Changes in Yield, Weight, and DMI}

Relationships between the slopes of change in behavior and production traits were estimated as correlation coefficients. Most of these correlations were weak, except for lying time and activity, which were negatively correlated during early lactation, and for eating time and DMI, which were positively correlated. Of note, these correlations are between slopes, not between mean values, for the same trait. However, the results suggest that the relationship between changes in behavior and yield and weight during lactation are either weak or more complex. 


\section{Differences Between Breed and Parity}

This study included both Holstein and Jersey cows kept under similar conditions and both primi- and multiparous cows of each breed. Compared with Holstein cows, Jersey cows, in most ways, followed the same pattern of changes during lactation but with different levels of recorded traits. Compared with Holstein cows, Jersey cows spent less time lying and eating and took more steps per day. This result confirms previous findings of higher activity in Jersey cows compared with Holstein cows, along with younger cows being more active than older cows (Løvendahl and Chagunda, 2006). A key morphological difference between these groups of cows is their size. For instance, the hip height of Jersey cows is around $90 \%$ that of Holstein cows (Enevoldsen and Kristensen, 1997). Thus, we speculate that breed differences in the number of steps might, at least in part, be explained by differences in cow size. However, because only one group of Jersey cows was included in the study, we cannot exclude the possibility that group effects might also explain some of the differences found between breeds.

In conclusion, in this study, Jersey cows spent less time lying and eating but took more steps than Holstein cows, with distinct trajectories during lactation that differed between parity.

\section{ACKNOWLEDGMENTS}

This work received funding from the SmartCow, a project funded by the European Union's Horizon 2020 research and innovation programme under the Grant Agreement no. 730924, from Mælkeafgiftsfonden (Milk Levy Fund, Denmark) and was supported by a Grand Solutions Prize, from Innovation Fund Denmark (Copenhagen, Denmark). The authors thank the staff at the Danish Cattle Research Centre for their committed engagement during the experiment. Connie H. Middelhede and Martin Bjerring (Department of Animal Science, Aarhus University, Tjele, Denmark) are acknowledged for contributing to data processing. The authors have not stated any conflicts of interest.

\section{REFERENCES}

Arazi, A., E. Ishay, and E. Aizinbud. 2010. The use of a new sensor (behavior tag) for improving heat detection, health and welfare monitoring in different rearing conditions. Pages 113-127 in Farm Animal Breeding, Identification, Production Recording and Management: Proc. 37th ICAR Biennial Session, Riga, Latvia. E. Skujina, E. Galvanoska, O. Leray, and C. Mosconi, ed. ICAR, Rome, Italy.

Beauchemin, K. A. 2018. Invited review: Current perspectives on eating and rumination activity in dairy cows. J. Dairy Sci. 101:47624784. https://doi.org/10.3168/jds.2017-13706.
Bewley, J. M., R. E. Boyce, J. Hockin, L. Munksgaard, S. D. Eicher, M. E. Einstein, and M. M. Schutz. 2010. Influence of milk yield, stage of lactation, and body condition on dairy cattle lying behaviour measured using an automated activity monitoring sensor. J. Dairy Res. 77:1-6. https://doi.org/10.1017/S0022029909990227.

Bossen, D., and M. R. Weisbjerg. 2009. Allocation of feed based on individual dairy cow live weight changes. II. Effect on milk production. Livest. Sci. 126:273-285. https://doi.org/10.1016/j.livsci 2009.07.011.

Bossen, D., M. R. Weisbjerg, L. Munksgaard, and S. Højsgaard. 2009. Allocation of feed based on individual dairy cow live weight changes I: Feed intake and live weight changes during lactation. Livest. Sci. 126:252-272. https://doi.org/10.1016/j.livsci.2009.07.010.

Brzozowska, A., M. Lukaszewicz, G. Sender, D. Kolasinska, and J. Oprzadek. 2014. Locomotor activity of dairy cows in relation to season and lactation. Appl. Anim. Behav. Sci. 156:6-11. https:// doi.org/10.1016/j.applanim.2014.04.009.

Buffington, D. E., A. Collazo-Aruchu, H. H. Canton, D. Pritt, W. Thatcher, and R. J. Collier. 1981. Black globe-humidity index (BGHI) as comfort equation for cows. Trans. ASAE 24:0711-0714. https://doi.org/10.13031/2013.34325.

Caja, G., A. Castro-Costa, and C. H. Knight. 2016. Engineering to support wellbeing of dairy animals. J. Dairy Res. 83:136-147. https://doi.org/10.1017/S0022029916000261.

Campler, M. R., M. B. Jensen, and L. Munksgaard. 2018. The effect of deep straw versus cubicle housing on behaviour during the dry period in Holstein cows. Appl. Anim. Behav. Sci. 209:1-7. https:/ /doi.org/10.1016/j.applanim.2018.10.004.

Chaplin, S., and L. Munksgaard. 2001. Evaluation of a simple method for assessment of rising behaviour in tethered dairy cows. Anim. Sci. 72:191-197. https://doi.org/10.1017/S1357729800055685.

DeVries, T. J., M. A. G. von Keyserlingk, D. M. Weary, and K. A. Beauchemin. 2003. Measuring the feeding behavior of lactating dairy cows in early to peak lactation. J. Dairy Sci. 86:3354-3361. https://doi.org/10.3168/jds.S0022-0302(03)73938-1.

Dohme-Meier, F., L. D. Kaufmann, S. Görs, P. Junghans, C. C. Metges, H. A. van Dorland, R. M. Bruckmaier, and A. Münger. 2014. Comparison of energy expenditure, eating pattern and physical activity of grazing and zero-grazing dairy cows at different time points during lactation. Livest. Sci. 162:86-96. https://doi.org/10 .1016/j.livsci.2014.01.006.

EFSA (European Food Safety Authority). 2009. Scientific report on the effects of farming systems on dairy cow welfare and disease. European Food Safety Authority (EFSA), Parma, Italy.

Envoldsen, C., and T. Kristensen. 1997. Estimation of body weight from body size measurements and body condition scores in dairy cows. J. Dairy Sci. 80:1988-1995.

Galán, E., P. Llonch, A. Villagrá, H. Levit, S. Pinto, and A. del Prado. 2018. A systematic review of non-productivity-related animalbased indicators of heat stress resilience in dairy cattle. PLoS One 13:e206520. https://doi.org/10.1371/journal.pone.0206520.

Hänninen, L., H. Hepola, J. Rushen, A. M. de Passillé, P. Pursiainen, V. M. Tuure, L. Syrjälä-qvist, M. Pyykkönen, and H. Saloniemi. 2003. Resting behaviour, growth and diarrhoea incidence rate of young dairy calves housed individually or in groups in warm or cold buildings. Acta Agric. Scand. A Anim. Sci. 53:21-28. https:/ /doi.org/10.1080/09064700310002008.

Henriksen, J. C. 2019. Effects of individual cow concentrate strategies on production and behaviour. PhD thesis. Department of Animal Science, Aarhus University, Tjele, Denmark.

Henriksen, J. C., and L. Munksgaard. 2019. Validation of AfiTagII, a device for automatic measuring of lying behaviour in Holstein and Jersey cows on two different bedding materials. Animal 13:617621. https://doi.org/10.1017/S1751731118001623.

Henriksen, J. C. S., M. R. Weisbjerg, P. Løvendahl, T. Kristensen, and L. Munksgaard. 2019. Effects of an individual cow concentrate strategy on production and behavior. J. Dairy Sci. 102:2155-2172. https://doi.org/10.3168/jds.2018-15477.

Huzzey, J. M., T. J. DeVries, P. Valois, and M. A. G. von Keyserlingk. 2006. Stocking density and feed barrier design affect the feeding 
and social behavior of dairy cattle. J. Dairy Sci. 89:126-133. https: //doi.org/10.3168/jds.S0022-0302(06)72075-6.

Ito, K., D. M. Weary, and M. A. G. von Keyserlingk. 2009. Lying behavior: Assessing within- and between-herd variation in free-stallhoused dairy cows. J. Dairy Sci. 92:4412-4420. https://doi.org/10 $.3168 /$ jds.2009-2235.

Kristensen, T., C. Jensen, S. Østergaard, M. R. Weisbjerg, O. Aaes, and N. Nielsen. 2015. Feeding, production, and efficiency of Holstein-Friesian, Jersey, and mixed-breed lactating dairy cows in commercial Danish herds. J. Dairy Sci. 98:263-274. https://doi .org $/ 10.3168 /$ jds.2014-8532.

Li, B., F. Fikse, P. Løvendahl, J. Lassen, M. Lidauer, P. Mäntysaari, and B. Berglund. 2018. Genetic heterogeneity of feed intake, energy-corrected milk, and body weight across lactation in primiparous Holstein, Nordic Red, and Jersey cows. J. Dairy Sci. 101:1001110021. https://doi.org/10.3168/jds.2018-14611.

Løvendahl, P., and M. G. G. Chagunda. 2006. Assessment of fertility in dairy cows based on electronic monitoring of their physical activity. CD commun. 18-04 in Book of Abstracts, World Congr. Genet. Appl. Livest. Prod., Belo Horizonte, Brazil.

Løvendahl, P., and L. Munksgaard. 2016. An investigation into genetic and phenotypic variation in time budgets and yield of dairy cows. J. Dairy Sci. 99:408-417. https://doi.org/10.3168/jds.2015-9838.

Maselyne, J., M. Pastell, P. T. Thomsen, V. M. Thorup, L. Hänninen, J. Vangeyte, A. Van Nuffel, and L. Munksgaard. 2017. Daily lying time, motion index and step frequency in dairy cows change throughout lactation. Res. Vet. Sci. 110:1-3. https://doi.org/10 $.1016 /$ j.rvsc.2016.10.003.

Munksgaard, L., M. B. Jensen, L. J. Pedersen, S. W. Hansen, and L. Matthews. 2005. Quantifying behavioural priorities-Effects of time constraints on behaviour of dairy cows, Bos taurus. Appl. Anim. Behav. Sci. 92:3-14. https://doi.org/10.1016/j.applanim .2004.11.005.

Norring, M., J. Häggman, H. Simojoki, P. Tamminen, C. Winckler, and M. Pastell. 2014. Short communication: Lameness impairs feeding behavior of dairy cows. J. Dairy Sci. 97:4317-4321. https:/ /doi.org/10.3168/jds.2013-7512.

Norring, M., A. Valros, and L. Munksgaard. 2012. Milk yield affects time budget of dairy cows in tie-stalls. J. Dairy Sci. 95:102-108. https://doi.org/10.3168/jds.2010-3458.

Olofsson, J. 1999. Competition for total mixed diets fed for ad libitum intake using one or four cows per feeding station. J. Dairy Sci. 82:69-79. https://doi.org/10.3168/jds.S0022-0302(99)75210-0.

Österman, S., and I. Redbo. 2001. Effects of milking frequency on lying down and getting up behaviour in dairy cows. Appl. Anim. Behav. Sci. 70:167-176. https://doi.org/10.1016/S0168-1591(00)00159-3.

Reader, J. D., M. J. Green, J. Kaler, S. A. Mason, and L. E. Green. 2011. Effect of mobility score on milk yield and activity in dairy cattle. J. Dairy Sci. 94:5045-5052. https://doi.org/10.3168/jds .2011-4415.

Sepúlveda-Varas, P., D. M. Weary, and M. A. G. von Keyserlingk. 2014. Lying behavior and postpartum health status in grazing dairy cows. J. Dairy Sci. 97:6334-6343. https://doi.org/10.3168/ jds.2014-8357.
Shan, C., J. Guo, X. Sun, X. Yang, J. Zhao, C. Wang, D. Qiu, Y. Wang, M. Feng, and Y. Gao. 2019. Correlation between behavior and milk yield of dairy cows. Int. J. Agric. Biol. 21:93-98.

Solano, L., H. W. Barkema, E. A. Pajor, S. Mason, S. J. LeBlanc, C. G. R. Nash, D. B. Haley, D. Pellerin, J. Rushen, A. M. de Passille, E. Vasseur, and K. Orsel. 2016. Associations between lying behavior and lameness in Canadian Holstein-Friesian cows housed in freestall barns. J. Dairy Sci. 99:2086-2101. https://doi.org/10 .3168/jds.2015-10336.

Steensels, M., C. Bahr, D. Berckmans, I. Halachmi, A. Antler, and E. Maltz. 2012. Lying patterns of high producing healthy dairy cows after calving in commercial herds as affected by age, environmental conditions and production. Appl. Anim. Behav. Sci. 136:88-95. https://doi.org/10.1016/j.applanim.2011.12.008.

Stone, A. E., B. W. Jones, C. A. Becker, and J. M. Bewley. 2017. Influence of breed, milk yield, and temperature-humidity index on dairy cow lying time, neck activity, reticulorumen temperature, and rumination behavior. J. Dairy Sci. 100:2395-2403. https://doi .org/10.3168/jds.2016-11607.

Thomsen, P. T., L. Munksgaard, and J. T. Sørensen. 2012. Locomotion scores and lying behaviour are indicators of hoof lesions in dairy cows. Vet. J. 193:644-647. https://doi.org/10.1016/j.tvjl .2012.06.046.

Thorup, V. M., L. Munksgaard, P. E. Robert, H. W. Erhard, P. T. Thomsen, and N. C. Friggens. 2015. Lameness detection via legmounted accelerometers on dairy cows on four commercial farms. Animal 9:1704-1712. https://doi.org/10.1017/S1751731115000890.

USDA. 2019. Milk production. Accessed January 15, 2020. https:/ /downloads.usda.library.cornell.edu/usda-esmis/files/h989r321c/ v692tn67x/9019sj173/mkpr1219.pdf.

Vasseur, E., J. Rushen, D. B. Haley, and A. M. de Passillé. 2012. Sampling cows to assess lying time for on-farm animal welfare assessment. J. Dairy Sci. 95:4968-4977. https://doi.org/10.3168/ jds.2011-5176.

Westin, R., A. Vaughan, A. M. de Passillé, T. J. DeVries, E. A. Pajor, D. Pellerin, J. M. Siegford, E. Vasseur, and J. Rushen. 2016. Lying times of lactating cows on dairy farms with automatic milking systems and the relation to lameness, leg lesions, and body condition score. J. Dairy Sci. 99:551-561. https://doi.org/10.3168/jds .2015-9737.

Zobel, G., D. M. Weary, K. E. Leslie, and M. A. G. von Keyserlingk. 2015. Invited review: Cessation of lactation: Effects on animal welfare. J. Dairy Sci. 98:8263-8277. https://doi.org/10.3168/jds.2015 -9617 .

\section{ORCIDS}

L. Munksgaard ๑ https://orcid.org/0000-0002-6343-0425

M. R. Weisbjerg @ https://orcid.org/0000-0002-6514-9186

J. C. S. Henriksen @ https://orcid.org/0000-0002-8926-5405

P. Løvendahl ๑ https://orcid.org/0000-0002-9852-2944 